\title{
Beyond War Narratives
}

\section{Laying Bare the Structural Violence of the Pandemic}

\section{Eliana Cusato}

Scrivere è sempre nascondere qualcosa in modo che venga poi scoperto. ${ }^{1}$

There has been much discussion about the importance of narratives for our understanding of the COVID-19 pandemic and its impact on the existing legal, political, and economic order. ${ }^{2}$ The vast literature that emerged following the outbreak of the pandemic shows how members of international law interpretative community have leveraged different cognitive frames in support of particular normative and policy agendas. Thus, international lawyers have extensively debated the possibilities and perils that come with mobilising discrete legal regimes to respond to the pandemic, notably international human rights, public health, migration, and investment laws. This reaction can also be read as a (reassuring) indication of the capacity of the discipline to subsume the COVID-19 'crisis' into existing legal categories in order to make sense of it and manage its consequences. ${ }^{3}$ In this chapter, I will consider some implications of the narrative framing the pandemic as an international peace and security issue, which can be seen as the epitome of crisis narratives. While I share the concerns expressed by other commentators

1 I. Calvino, Se una notte d'inverno un viaggiatore (Oscar Mondadori, 2016) at 193, tr. 'writing always means hiding something in such a way that it then is discovered'.

2 A. Roberts and N. Lamp, 'Is the Virus Killing Globalization? There's No One Answer', Barron's, 15 March 2020.

3 See J. D'Aspremont, 'International Law as a Crisis Discourse: The Peril of Wordlessness', in this collection. 
about the 'securitisation' of the pandemic, ${ }^{4}$ my aim is to contribute to this discussion from a different angle. Using the concept of structural violence, I intend to shed light on the socio-economic-ecologic violence that pre-exist and persist beyond the COVID-19 'crisis' and that the vocabulary of war/insecurity conceals. To put it differently, I am interested in exploring what is at stake in the acts of framing and, in Judith Butler's words, the 'orchestrating designs of the authority who sought to control the frame. ${ }^{5}$ If war talk, as other crisis discourses, allows for a simplified normative agenda, what gets elided in such accounts of the pandemic? What does this exclusion tell us about international law and lawyers?

I will start by outlining the role of legal practices in the securitisation/militarisation of the pandemic, which is in line with more general developments in international law, the most relevant example being the definition of climate change as a 'threat multiplier'. 6 The rhetoric of war/insecurity applied to complex social phenomena, such as global warming or pandemics, creates a shared sense of vulnerability vis-à-vis the enemy and obfuscates the differentiated effects suffered by the most marginalised. Following Johan Galtung and Paul Farmer, I will then re-define the pandemic, and its uneven impacts, as instance of violence that is 'built into the structure' and that cannot be accounted for by the dominant liability-based model of international law. Lastly, I will argue that the narrative framing the virus as the 'enemy', or an external threat to peace and security, obscures the complex interconnection between humanity, economy, and ecology. In reproducing this separation, international law shows (at least) a myopic attitude to the root causes of the pandemic, which are the same of the ecological breakdown: exploitation of fellow humans and nature. ${ }^{7}$ I will conclude by reflecting on the responsibility that comes with 'naming' the violence of the pandemic and the prospects of changing master narratives in international law.

4 C. Connolly, 'War and the Coronavirus Pandemic', 15 TWAILR Reflections, 9 April 2020; C. Schwöbel-Patel 'We Don't Need a 'War' against Coronavirus. We Need Solidarity', Al Jazeera, 6 April 2020.

5 J. Butler, Frames of War: When is Life Grievable? (Verso 20o9), at 12.

6 See Report of the Secretary-General on Climate Change and its Possible Security Implications, UN Doc. A/64/350, 11 September 2009.

7 On the relationship between exploitation and international law, see S. Marks, 'Exploitation as an International Legal Concept', in S. Marks (ed.) International Law on the Left (CuP 2008), 281. 
War metaphors are pervasive in public discussions of everything from political campaigns to battles with cancer to wars against organised crime, drugs, poverty. ${ }^{8}$ Likewise, as put by Arundhati Roy, 'the mandarin who are managing this pandemic are fond of speaking of war. They don't even use war as a metaphor, they use it literally'. ${ }^{9}$ Donald Trump declared himself a 'wartime president' and proclaimed in a Tweet 'We will win this war; ${ }^{10}$ Boris Johnson announced that "We must act like any wartime government';11 and Emmanuel Macron said 'We are in a war' in which 'nothing should divert us' from fighting an 'invisible enemy.'.12 The invocation of war in discussions on the pandemic is not limited to head of states. David Katz, founding director of the Yale-Griffin Prevention Research Center, observed that

We routinely differentiate between two kinds of military action: the inevitable carnage and collateral damage of diffuse hostilities, and the precision of a "surgical strike," methodically targeted to the sources of our particular peril. The latter, when executed well, minimizes resources and unintended consequences alike. As we battle the coronavirus pandemic, and heads of state declare that we are "at war" with this contagion, the same dichotomy applies. This can be open war, with all the fallout that portends, or it could be something more surgical. ${ }^{13}$

The language of 'inevitable collateral damage' and 'precision warfare' are undoubtedly familiar to international lawyers. The regulation of hostilities is, after all, one of the most developed area of international law. While many international lawyers would agree that the war metaphor is entirely inaccurate for the situation we are facing, it is equally true that the professional discipline of international law has become an integral part of the securitisation and militarisation of international affairs. ${ }^{14}$ If, as put by Judith Butler, 'the frames that, in effect, decide what lives will be recognizable as lives and which will not,

8 S.J. Flusberg 'War Metaphors in Public Discourse', 33(1) Metaphor and Symbol (2018) 1.

9 A. Roy, 'The Pandemic is a Portal', Financial Times, 3 April 2020.

$10 \mathrm{https} / / /$ twitter.com/realdonaldtrump/status/1244029041432244224.

11 https://www.bbc.com/news/av/uk-5193676o.

12 https://www.bbc.com/news/av/51917380.

13 D.L. Katz, 'Is Our Fight Against Coronavirus Worse Than the Disease?', New York Times, 20 March 2020.

14 N. Tzouvala, 'COVID-19, International Law and the Battle for Framing the Crisis', International Law Association Reporter, 25 March 2020. 
must circulate in order to establish their hegemony', ${ }^{15}$ the role of international law - understood as a discipline, a normative project, and a practice - in the circulation of specific narratives deserves to be carefully considered.

Ongoing academic and policy debates on the whether the pandemic gives rise to a threat to international peace and security and fits within the mandate of the United Nations Security Council (UNSC) are an indication of the power and responsibility of the legal interpretive community. ${ }^{16}$ In its remarks to the UNSC, in April 2020, the UN Secretary-General has called the coronavirus pandemic the 'fight of a generation' and a significant threat to the maintenance of international peace and security. ${ }^{17}$ Antonio Guterres warned the UNSC that the pandemic had the potential to increase social unrest and violence, which would greatly undermine the world's ability to fight the disease. On 1 July 2020 the UNSC followed up and unanimously adopted Resolution 2532, recognising that the unprecedented extent of the novel coronavirus pandemic 'is likely to endanger the maintenance of international peace and security'.18 The Resolution also " $[d]$ emand $[e d]$ a general and immediate cessation of hostilities in all situations on its agenda" (para. 1) and call[ed] upon all parties to armed conflicts to engage immediately in a durable humanitarian pause for at least 9o consecutive days (para. 2). However, interestingly, the general and immediate cessation of hostilities and humanitarian pause do not apply to military operations against the Islamic State in Iraq and the Levant (ISIL/ Da'esh), Al-Qaida, and all other Council-designated terrorist groups (para. 3). The 'war on terror' seems, in other words, compatible with the 'war' against the Covid-19 pandemic.

For some commentators, framing COVID-19 as a peace and security issue is plausible and a natural outcome.$^{19}$ The precedent invoked is the UNSC's response to the Ebola crisis in West Africa, which Resolution 2177 (2014) characterised as a 'threat to international peace and security'. ${ }^{20}$ As such, the conclusion is reached that there is an arguable case for the Security Council to act in response to COVID-19, although it remains unclear what kind of measures

\footnotetext{
15 Butler, supra note 5 , at 12.

16 M. Windsor, 'Narrative Kill or Capture: Unreliable Narration in International Law', 28 Leiden Journal of International Law (2015) 743, at 765-768.

17 UN Secretary-General's Remarks to the Security Council on the Covid-19 Pandemic, 9 April 2020.

18 UNSC Resolution 2532, 1 July 2020, UN Doc. S/RES/2532 (2020).

19 M. Svicevic, 'COVID-19 as a Threat to International Peace and Security: What place for the UN Security Council?', EJIL:Talk!, 27 March 2020. UNSC Resolution 2177, 18 September 2014, UN Doc. S/RES/2177 (2014).
} 
the UNSC should take. ${ }^{21}$ Security Council actions are, in other words, presented as a necessary and desirable means to manage and contain the 'crisis of disorder facing the world'.22 Other international legal scholars, however, have warned that the militarised language may encourage counter-productive responses at the domestic and international level. Christine Schwöbel-Patel observes that "[a]lthough the enemy is invisible, war talk nevertheless creates the spectre of an enemy. And, because war is associated with the 'other', war talk has the tendency to create and build on ethno-nationalist sentiment.' ${ }^{23}$ For Ntina Tzouvala the 'war' narrative has the potential of expanding executive power and increasing tensions between states. ${ }^{24}$ Rather than encouraging international solidarity and compassion, the militarised language suggests the need for measures to defend ourselves against 'a shadowy enemy'.25

It is important to note that the securitisation of COVID-19 is not atypical, but in line with recent developments in international law. Over the last couple of decades the UNSC has been expanding its primary responsibility for the maintenance of international peace and security (under Article 24 of the UN Charter), by affirming its jurisdiction over a variety of issues, such as human rights violations, gendered violence, humanitarian disasters, illicit trade in natural resources, organised crime, and infectious diseases. ${ }^{26}$ Recently, climate change has been approached through an international security lens and as a subject matter that could be addressed by the UNSC. ${ }^{27}$ In 2007, 2011 and 2018 the UNSC hosted thematic debates on the implications of climate change for international security, thereby asserting a link between anthropogenic climate

21 E. Pobjie, 'Covid-19 as a Threat to International Peace and Security: The Role of the UN Security Council in Addressing the Pandemic, EJIL:Talk!, 27 July 2020. A. Orford, 'The Politics of International Security', 17 Michigan Journal of International Law (1996) 373, at 400 .

23 Schwöbel-Patel, supra note 4.

24 Tzouvala, supra note 14.

25 Connolly, supra note 4.

26 For a critique of the expansion of the authority of the UNSC over 'new' challenges to international peace and security, with specific regards to the Women, Peace and Security Agenda, see G. Heathcote, 'Women and Children and Elephants as Justification for Force', 4Journal on the Use of Force and International Law (2017) 66.

27 See Report of the Secretary-General on Climate Change and its Possible Security Implications, UN Doc. A/64/350, 11 September 2009. In the literature, see e.g. S.V. Scott and C. Ku, Climate Change and the UN Security Council (Edward Elgar 2018); S.V. Scott, 'Climate Change and Peak Oil as Threats to International Peace and Security: Is It Time for the Security Council to Legislate', 9 Melb J Int'l L (2008) 495; K. Davies, T. Riddell, and J. Scheffran, 'Preventing a Warming War: Protection of the Environment and Reducing Climate Conflict Risk as a Challenge of International Law', 10 Goettingen Journal of International Law (2020) 307. 
change and increased rate of violence. ${ }^{28}$ However, in a field were sensitivities are rapidly shifting, the meaning of 'security' in relation to climate change is increasingly viewed as 'a site of contestation between alternative discourses' or world views. ${ }^{29}$ This is illustrated by the statements made by developing and small-island states in the context of UNSC thematic debates mentioned above. Global South countries disproportionately impacted by climate change consider conventional notions of security, grounded on military intervention or stabilisation, as ineffective in coping with the complex reality of climate change. ${ }^{30}$ Many countries also expressed skepticism as to whether the UNSC would be the appropriate institutional body to deal with climate change given the broader causes and consequences of climate breakdown. ${ }^{31}$

In a similar vein, the 'securitisation' of the pandemic raises the question of the nature of the 'threat' posed and to whom. As in the case of climate change, the uneven impacts of the pandemic upon the most marginalised individuals and communities are a matter of concern. ${ }^{32}$ The rhetoric of war/insecurity creates a shared sense of vulnerability vis-à-vis the enemy, thus obfuscating the differentiated effects of the pandemic according to privilege or vulnerability. The depiction of COVID-19 as a peace and security issue diverts attention away from the heterogeneity of human societies and the 'geographies of injustice. ${ }^{33}$ As a result, it promotes an apolitical approach to deaths and suffering, and discourages the search for their underlying causes. ${ }^{34}$ Hence, rather than looking at the violence allegedly 'caused' by the virus and falling in the trap

28 See UnSC, 5663rd Meeting, Security Council Open Debate: Energy, Security and Climate, UN Doc. s/PV.5663 and UN Doc. s/PV.5663 Resumption 1 (2007); Unsc, 6587th Meeting, Security Council Open Debate: Maintenance of International Peace and Security: The Impact of Climate Change, UN Doc. s/PV.6587 and UN Doc. S/PV.6587 Resumption 1 (2011); UNSC, 8307th meeting, Security Council Open Debate: Understanding and Addressing Climate-Related Security Risks, UN SCOR, UN Doc S/PV.8307 (2018), 11 July 2018.

29 M. McDonald, 'Climate Change and Security: Towards Ecological Security?', 10 International Theory (2018) 153, at 158.

30 See e.g. the interventions of the representatives of Nauru, Maldives and Trinidad and Tobago at the UNSC debate Understanding and Addressing Climate-Related Security Risks, UN SCOR, UN Doc S/PV.83O7 (2018), 11 July 2018.

31 See e.g. the statement of the representative of the Democratic Republic of the Congo at the 2007 UNSC open debate, supra note 28 , at 7 .

32 K. Evelyn, "It's a racial justice issue": Black Americans are dying in greater numbers from Covid-19, The Guardian, 8 April 2020.

33 U. Baxi, 'Towards a Climate Change Justice Theory?', 7(1) Journal of Human Rights and the Environment (2016) 7, at 9.

L. Hartmann-Mahmud, 'War as Metaphor', 14 Peace Review (2002) 427, at 427-428. 
of environmental/social determinism, in the next section I suggest that we should analyse the pandemic as an instance of structural violence.

\section{$2 \quad$ Understanding the Pandemic via Structural Violence}

Writing in 1969, Johan Galtung called attention to pervasive forms of violence that are 'built into the structure' and that manifest themselves as inequality of power, resources and life chances. ${ }^{35}$ In a passage which seems to speak to the current situation, he claims that 'if a person died from tuberculosis in the eighteen century, it would be hard to conceive this as violence since it might have been quite unavoidable, but if he dies from it today, despite all the medical resources in the world, then violence is present according to our definition'. Anthropologist and medical doctoral Paul Farmer built upon Galtung's concept of structural violence to study the tuberculosis and HIV epidemics that killed millions of people in Haiti. ${ }^{36} \mathrm{He}$ found that historical political economic domination and inequalities created a society that is ravaged by these diseases, which could be avoided or at least made less severe. Both Galtung and Farmer warn that through focusing on forms of violence that are more immediately visible and directly carried out, we fail to appreciate the structures that systemically distribute life chances in an unequal way.

While the war metaphor and the language of 'crisis' distracts us from the 'politics of everyday life', to use Hilary Charlesworth's words, ${ }^{37}$ by attending to the structural violence of the pandemic we are able to see forms of violence that pre-exist and persist far beyond the emergency. As Lutz Otte put it, CoviD-19 has brought into sharp relief the 'systemic institutional shortcomings and the realities of precarious lives': weak public health systems, overcrowded prisons and immigration detention facilities are breeding grounds for infections. ${ }^{38}$ The 'securitisation' of the pandemic disguises these structural issues that result in the pandemic being effectively out of control in many countries with the most vulnerable and disenfranchised being hit the worst. The coronavirus pandemic has revealed how a globalised economy based on profit accumulation and consumerism, sustained by international legal norms and institutions, has deepened existing inequalities between the Global North and Global South, as well

35 J. Galtung, 'Violence, Peace and Peace Research', 6(3) Journal of Peace Research (1969) 167.

36 P. Farmer, 'An Anthropology of Structural Violence', 45(3) Current Anthropology (2004) 305.

37 For a call to refocus international law on issues of structural justice, see H. Charlesworth,' International Law: A Discipline of Crisis', 65 The Modern Law Review (2002) 377.

38 L. Oette, 'How is Covid-19 impacting Human Rights?', soAs Blog, 30 March 2020. 
as within countries in the North. ${ }^{39}$ In South East Asia, the virus has exposed the weak social protection for urban poor, especially migrant workers, ${ }^{40}$ while for many African people working in the informal sector social distancing is a privilege they cannot afford. ${ }^{41}$

Do we have a legal vocabulary to account for this violence? One of the merits of Galtung's concept of structural violence is that it opens up the category beyond visible, direct and immediate infliction of harm to include social ills, such as poverty, subordination, and exclusion. According to Yves Winter, the traditional definitions restrict violence to the 'international, direct, immediate and visible infliction of physical harm, the assault or encroachment on the physical integrity of another human being or his or her property'.42 Galtung argues that personal violence 'shows', whereas structural violence 'is silent, it does not show - it is essentially static, it is the tranquil waters. In a static society, personal violence will be registered, whereas structural violence may be seen as about as natural as the air around us'43 Of course, there is nothing 'natural' about millions of people dying for an infective disease, especially where evidence demonstrates the differentiated impacts across racial, gender, and class lines. Yes, the ceaseless repetition of this everyday violence makes it normal and thus invisible.

If we think about CoviD-19 in these terms, one important insight for international lawyers is that this form of violence (contrary to 'personal' violence) does not presuppose an intentional agent as perpetrator and cannot be accounted for by liability-based models. It cannot be easily attributed to an 'enemy' (in our case, the virus) or to a state's conduct. This raises a number of challenges for a legal system built around the liberal notions of agency, attribution, control, and causation. It also suggests that we need a more resilient set of concepts that goes beyond the juridical grammar that requires every violence to be attached to a subject. ${ }^{44}$ Further, as I will contend in the next section,

39 See e.g. J. Linarelli, M.E Salomon, and M. Sornarajah, The Misery of International Law (OUP 2018).

40 Chen Chen Lee, 'The Coronavirus Crisis Is Laying Bare Southeast Asia's Inequality Problem', The Diplomat, 8 April 2020.

41 K. Noko, 'In Africa Social Distancing is a Privilege Few Can Afford', Al Jazeera, 22 March 2020.

42 Y. Winter, 'Violence and Visibility', 34(2) New Political Science (2012) 195, at 196. The commentator outlines also the limits of Galtung's term, i.e. its vagueness and the neglect of 'the specific differences and historical variations of forms of injustice, their intersections, and the ways in which they are compounded'. Ibid. at 195.

43 Galtung, supra note 35, at 173.

44 Winter, supra note 42 , at 197. 
international law needs to overcome the artificial separation between humanity, ecology, and economy, which makes it unable to account for the root causes of the pandemic.

\section{Root Causes: The Interconnection of Humanity, Ecology, and Economy}

COVID-19 is an animal-borne disease which, according to the most diffused (yet controversial) reconstruction, was transmitted to a human by an animal kept in a wet market of Wuhan in China. The war narrative framing the virus as the 'enemy' or a threat to international peace and security is based upon an artificial separation between humans and nature. On the contrary, the rise in zoonotic diseases (like CoviD-19) shows the profound interconnection between human wellbeing and the way we treat other living beings and entire ecosystems. The United Nations Environment Programme (UNEP) underlines that 6 o per cent of all infectious diseases in humans are zoonotic, as are 75 per cent of all emerging infectious diseases. ${ }^{45}$ In relation to previous outbreaks, UNEP notes that:

The Ebola outbreak in West Africa [2014-2016] was the result of forest losses leading to closer contacts between wildlife and human settlements; the emergence of avian influenza [first detected in humans in 1997] was linked to intensive poultry farming; and the Nipah virus [1998-1999] was linked to the intensification of pig farming and fruit production in Malaysia. ${ }^{46}$

By defining the virus as something 'external' to our society, we turn a blind eye to the centrality of nature in the existing socio-economic order. ${ }^{47}$ Industrial growth and production systems shape the ecological world and are in turn shaped by new and emerging ecological relations. As observed by Ntina Tzouvala, it is misleading to frame the virus as the product of Chinese underdevelopment; instead, we should see it as the result of the country's rapid

45 UNEP, Six Nature Facts Related to Coronaviruses, 8 April 2020, https://www.unep.org/ news-and-stories.

46 Ibid.

47 T. Ferrando, 'Let's Not be Fooled: There's Nothing External and Symmetrical in the Global Economic Downturn', Critical Legal Thinking, 8 April 2020. 
development and incorporation into a globalised economy. ${ }^{48}$ The disruption of forests and landscape fragmentation caused by rapid urbanisation and intensive farming have created new opportunities for zoonotic diseases, by helping to align the three core elements needed for disease transmission - a pathogen, a host and a vector.

Rather than pointing the finger at wet markets, we should look at how unsustainable development practices, often facilitated by international legal norms conceptualising nature as property or resource to be exploited, ${ }^{49}$ resulted in increased habitat and biodiversity loss. As ecologists tell us that shrinking natural habitats and changing behaviour may create the conditions for new diseases like COVID-19 to arise in future, ${ }^{50}$ rethinking how we 'frame' the environment becomes an urgent task. ${ }^{51}$ The CoviD-19 pandemic has given renewed weight to such concerns, but it is important to note that these arguments in themselves are not new. Indeed, human-nature relations have occupied a significant place within feminist and critical ecology literature. ${ }^{52}$ Donna Haraway has pointed out that 'we must find another relationship to nature besides reification and possession. ${ }^{33}$ Vandana Shiva has emphasised the need to transcend the 'polarisation, divisions and exclusions that place the economy against ecology, development against environment and people against the planet and against one another in a new culture of hate. 54

The split between ecology and economy is something that critical legal scholars have also explored and challenged. ${ }^{55}$ It has been observed that, although

48 N. Tzouvala, 'The Combined and Uneven Geography of COVID-19, or on Law, Capitalism and Disease', Opinio Juris, 2 April 2020.

49 U. Natarajan and K. Khoday, 'Locating Nature: Making and Unmaking International Law', 27 Leiden Journal of International Law (2014), 573; I. Porras, 'Appropriating Nature: Commerce, Property, and the Commodification of Nature in the Law of Nations', 27 Leiden Journal of International Law (2014) 641; S. Pahuja, 'Conserving the World's Resources?', in J. Crawford and M. Koskenniemi (eds.) The Cambridge Companion to International Law (CUP 2012) 398.

$5^{\circ}$ J. Vidal, "Tip of the iceberg”: Is Our Destruction of Nature Responsible for Covid-19?, The Guardian, 18 March 2020.

$5^{1}$ See e.g. G. Lakoff, 'Why It Matters How We Frame the Environment', 4 Environmental Communication (2010) 70.

52 See the seminal work of Donna Haraway, e.g. 'The Promises of Monsters: A Regenerative Politics for Inappropriate/d Others', in L. Grossberg, C. Nelson and P.A. Treichler (eds.) Cultural Studies (Routledge, 1992), 295. See also A. Biro (ed.) CriticalEcologies: The Frankfurt School and Contemporary Environmental Crises (University of Toronto Press, 2011).

53 Haraway, ibid. at 296.

54 V. Shiva, 'Earth Democracy: Creating Living Economies, Living Democracies, Living Cultures', 2 South Asian Popular Culture (2004), 5, at 11.

55 See e.g. A. Philippopoulous-Mihalopoulos (ed.) Law and Ecology: New Environmental Foundations (Routledge 2011); S. Humphrey and Y. Otomo, 'Theorizing International 
conservation and destruction of nature are mutually constitutive processes, the discipline of international law separates conceptually the rules that apply to nature to those that regulate the economy. ${ }^{56}$ International environmental law defines the 'environment' as an object of human protection, while international economic law constructs 'natural resources' as objects of appropriation and free commerce. Whereas the environment is regulated with the goal of stewardship, natural resources are governed with the aim of enabling their efficient exploitation. However, as agued by Julia Dehm and Usha Natarajan, 'when competing governance objectives are directed at an identical object, the result is regulatory dysfunction'.57 If the ecological breakdown and the covid19 pandemic have the same root-causes, meaning overconsumption, extractivism, and the unrestrained pursuit of economic growth, by severing humanity, economy and ecology, international law condemns itself to have peripheral impact upon the most pressing challenge facing our interconnected world.

This brings to the fore another key limitation of the war/security narrative. War talk does not engage in a full exploration of root causes. ${ }^{58}$ Lori HartmannMahmud explains that the vocabulary of war 'does not have time for analysis, for understanding, for dialogue. That is at once its strength and its weakness; it cuts through the competing versions of why and how the enemy has emerged and sharply focuses on attacking and defeating the enemy'.59 In doing so, it distracts attention from the very discussions that are indispensable for meaningfully addressing the problem.

\section{Of Frames, Power, and Responsibility}

Narratives in international law structure the terms of debate, as well as set limits on the kinds of policies and regulatory approaches regarded as suitable to address the issue at hand. Narratives, however, are not neutral, 'they investigate, but also suggest, create and legislate meanings' ${ }^{60}$ This short chapter sought to explore the normative implications of war metaphors and securitising

\footnotetext{
Environmental Law', in A. Orford and F. Hoffmann (eds.), The Oxford Handbook of the Theory of International Law (OUP 2016) 798.

56 Humphrey and Otomo, ibid. at 805 .

57 U. Natarajan and J. Dehm 'Where is the Environment? Locating Nature in International Law', TWAILR Reflections, 30 August 2019.

$5^{8}$ For similar arguments in relation to the human rights discourse, see S. Marks, 'Human Rights and Root Causes', 74 The Modern Law Review (2011) 57.

59 Hartmann-Mahmud, supra note 34, at 431.

6o M. Aristodemu, Law and Literature:Journeys from Her to Eternity (oup 2000), at 3.
} 
narratives as applied to the COVID-19 pandemic. It showed that war narratives simplify complex social phenomena to the point of distortion. As war involves a fight between opposing forces with a clear distinction between us ('good') and the enemy ('evil'), we are compelled to think that we are all experiencing death and suffering in the same way. That is not true. The pandemic has shed light on the unequal distribution of rights (including health rights) and vulnerability within and across countries. Further, war narratives mislead, as they proceed from the assumption that the enemy is separated and distinct from our society. This approach distorts our vision of the pandemic, blocking any alternative view that may see it as a symptom of the socio-economic system in place, which treats nature as a 'resource' to be exploited in the pursuit of endless growth. The virus is not the enemy, it does not hate us, it does not even know that we exist. This is not a war because wars are fought with the aim of defending or preserving a certain lifestyle or order. If this pandemic, and its devastating consequences, are a manifestation of structural violence, as I claimed, this requires a radical transformation of our hierarchy of values and ways of thinking. As presciently argued by Anne Orford 'those international lawyers who represent the current period in world history as one of order threatened by chaos again represent only one perspective: that of those who had a stake in the old order' ${ }^{61}$ Luckily, the international legal community is not uniform, instead it is characterised by multi-perspectival narrations and cognitive frames, ${ }^{62}$ as the discrete reactions to the Covid-19 'crisis' have highlighted. While some narratives are 'more equal than other', the possibility to contest dominant frames and create new ones should not be underestimated. Intellectual traditions that emphasise the interrelation of humanity and ecology, such as the ones recalled above, offer compelling visions to construct different frames. As put by Dianne Otto,

We need an international legal framework that can build solidarity rather than foster division, promote redistributive values rather than private enrichment, challenge the entrenched inequalities of the quotidian rather than normalizing and exploiting them, advance positive peace rather than militarism, and ensure environmental sustainability rather than degradation. ${ }^{63}$

61 Orford, supra note 22 , at 400.

62 Windsor, supra note16, at 765 .

63 D. Otto, 'Introduction' in D. Otto (ed.) Queering International Law: Possibilities, Alliances, Complicities, Risks (Routledge, 2018), at 2. 
Breaking with a frame not only generates the possibility of new frames and new content, but significantly discloses a 'taken-for-granted' reality. ${ }^{64} \mathrm{It}$ is both illuminating and empowering. Ultimately, international lawyers should pay attention to the ends that are at stake in framing the pandemic (and other 'crises'), reject narratives that oversimplify the reality, and take responsibility for the knowledge we produce and the stories we decide to tell. ${ }^{65}$

\section{Acknowledgments}

An earlier version of this chapter was published in the blog of the European Journal of International Law (EJIL:Talk!) in May 2020. Many thanks to Marija Jovanovich for her thoughtful comments on an earlier version of this chapter, as well as to the editors for their feedback.

64 S. Dehm, 'Framing International Migration', 3 London Review of International Law (2015) 133 , at 165 , referring to Judith Butler's important work cited above.

65 Orford, supra note 22 , at 408. 